\title{
Urgensi Layanan Informasi Berbasis Digital pada Pandemi Covid-19: Sebuah Tinjauan Kepustakaan Sistematis
}

\author{
Muhammad Ibnu Majah, Elva Oktafiani, Muhammad Thufeil Imtinan \\ UIN Sunan Kalijaga Yogyakarta, Indonesia \\ Contact: ibnumajah44@gmail.com
}

\begin{abstract}
Many published scientific studies from January-August 2021 discuss the COVID-19 pandemic and its relationship to digital technology. This publication demonstrates the ease of digital technology in helping the Indonesian people to deal with the COVID-19 pandemic. But in reality, the increase in the number of patients until the government implements the PPKM Mandiri policy (July-August 2021) continues to increase. The research method using a systematic literature review can find out what happened in Indonesia during the COVID-19 pandemic through published articles. The search for scientific literature was carried out using Mendeley References through the keywords digital technology and covid-19. The data obtained regarding the issue of digital technology and covid-19 and research in the territory of Indonesia obtained 80 articles. The data were analyzed and concluded that the largest research on online education is due to restrictions on face-to-face learning. Increasing the economy by strengthening digital technology to bring together buyers and sellers in tackling the decline in purchasing power and many transactions are written. However, technology to cope with the increasing number of patients and deaths due to the COVID-19 pandemic is not sufficiently considered in published scientific articles, so the public is not given sufficient knowledge about COVID-19 through digital technology. These results can provide input on digital technology policies that the Government of Indonesia should carry out to help reduce the number of patients and deaths due to the COVID-19 pandemic.
\end{abstract}

Keywords: Data analysis, digital technology, covid-19, systematic literature review

\begin{abstract}
ABSTRAK
Penelitian ilmiah yang terpublikasi dari bulan Januari-Agustus 2021 yang membahas pandemi covid-19 dan hubungannya dengan teknologi digital sangatlah banyak. Publikasi itu memperlihatkan kemudahan teknologi digital dalam membantu masyarakat Indonesia untuk menghadapi pandemi covid-19. Tetapi kenyataannya peningkatan jumlah pasien hingga pemerintah melakukan kebijakan PPKM Mandiri (Juli-Agustus 2021) tetap meningkat. Metode penelitian menggunakan systematic literaturee review dapat mengetahui sebenarnya apa yang terjadi di Indonesia dalam keadaan pandemi covid-19 melalui artikel yang terpublikasi. Pencarian literature ilmiah dilakukan menggunakan Mendeley References melalui kata kunci teknologi digital dan covid-19. Hasil data yang yang didapat mengenai isu Teknologi digital dan covid-19 dan penelitian di wilayah Indonesia didapatkan 80 Artikel. Data tersebut dianalisa dan disimpulkan bahwa penelitian yang terbesar mengenai Pendidian daring karena pembatasan adanya pembelajaran tatap muka. Peningkatan ekonomi dengan diperkuat teknologi digital untuk mempertemukan pembeli dan penjual dalam menanggulangi turunnya daya beli dan transaksi banyak ditulis. Tetapi teknologi untuk menanggulangi peningkatan angka pasien dan kematian karena pandemi covid-19 tidak diperhatikan cukup dalam artikel ilmiah yang terbit, sehingga masyarakat tidak diberikan pengetahuan cukup mengenai covid-19 melalui teknologi digital. Hasil ini dapat memberikan masukan pada kebijakan teknologi digital yang seharusnya dilakukan Pemerintah Indonesia untuk membantu penurunan angka pasien dan kematian karena pandemi covid-19.
\end{abstract}

Kata Kunci: analisis data, teknologi digital, covid-19, systematic literature review 


\section{Pendahuluan}

Perubahan budaya dalam kehidupan manusia setelah datangnya era teknologi yang memasuki aktivitas manusia mengubah segala cara pandang manusia ketika melihat dunianya. Manusia beraktivitas dengan mengikuti apa yang disajikan dalam layar sebuah gadget (Nunes, 2006:3). Dunia digital menjadi sesuatu yang vital ketika ada masalah dalam aktivitas manusia yang membutuhkan tindakan yang sangat cepat seperti dalam keadaan bencana alam yang sering terjadi di Indonesia. Peringatan dini pulalah yang dapat mengurangi ataupun meminimalisir kerugian akibat musibah alam. Inilah penanggulangan yang sebenarnya sesuatu yang harus dimiliki di Indonesia, mengingat negara Indonesia ialah negeri dengan kepulauan dimana peristiwa gempa, tsunami, serta kemampuan meletusnya gunung berapi adalah suatu ancaman musibah, yang harus segera dapat di deteksi awal bila akan terjadi sehingga kedudukan teknologi berupa data-data awal dapat dibagikan lebih dini. Data ini dapat menjadi suatu kemampuan untuk mencegah musibah alam di wilayah tertentu di Indonesia (Arifin, 2016:3). Mitigasi serta sistem peringatan dini yang mengedepankan teknologi digital telah menjadi keharusan di Indonesia. Sosialisasi ke masyarakat sebagai ujung tombak penangkalan kebencanaan yang kerap terjalin, membantu dalam menentukan kebijakan dan koordinasi dalam penanggulangan bencana yang terjadi pada suatu wilayah bencana (Arifin, 2016:1).

Sebagaimana saat ini, kita sangat memerlukan teknologi digital yang mempermudah masyarakat Indonesia untuk melakukan pencegahan atas pandemi covid-19. Suasana serta keadaan kesehatan dan kegiatan warga Indonesia sekarat sejak menyebarnya covid-19 pada bulan Maret 2020. Lalainya masyarakat seiring dengan ketidaktahuan dan ketidakpedulian dalam melaksanakan atau mempraktikkan protokol kesehatan dari melindungi jarak, cuci tangan, tidak berkerumun apalagi tidak mengenakan masker di ruang-ruang masyarakat beraktivitas jadi pemicu meningkatnya permasalahan penyebaran Covid- 19. Bersumber pada laman covid19.go.id pada Selasa 17 Agustus 2021, jumlah terkonfirmasi positif Covid-19 secara global sebanyak 183. 934. 913 orang serta jumlah yang wafat 4.361 .996 orang. Sedangkan jumlah yang terkonfirmasi positif di Indonesia sebanyak 3.892.479 orang, jumlah penderita sembuh 3.414.109 orang, serta jumlah permasalahan wafat menggapai 120.013 orang. Pertambahan permasalahan Covid-19. Pertarungan dengan covid-19 tiap hari dilakukan oleh pemerintah dengan bermacam edukasi. Materi edukasi itu melalui perangkat digital berupa SMS, WA, website, Influencer, bahkan media konvensional berupa informasi di TV maupun radio.. Bahkan menurut Kemeninfo, Pandemi Covid-19 telah mengubah hubungan interaksi masyarakat dunia untuk adaptif menggunakan teknologi digital (Yusuf, 2021). Bahkan beberapa organisasi melakukan pendekatan digital untuk menanggulangi masalah sosial di masyarakat seperti, membangun model basis penggunaan teknologi digital bagi UMKM dalam masa pandemi covid-19 (Liu \& Sukmariningsih, 2021).

Bersamaan dengan meluasnya penyebaran Covid- 19 di Indonesia, hingga pemerintah membuat peraturan program harus vaksin. Perihal ini diatur dalam 
Peraturan Presiden (PERPES) No 14 Tahun 2021 selaku Pergantian atas Perpes No 99 Tahun 2020 tentang " Pengadaan serta Penerapan Vaksinansi Dalam Rangka Penanggulangan Pandemi Corona Virus Disease 2019( COVID- 19)". Dikeluarkannya Perpes tersebut, hingga jadi kewajiban untuk segala warga buat melaksakan program vaksinasi. Bahkan informasi terakhir di laman we covid.go.id, Indonesia kedatangan vaksin COVID-19 tahap ke-37 pada 16 Agustus 2021 menghadirkan 5 juta dosis vaksin jadi produksi Sinovac, yang juga dikenal dengan sebutan CoronaVac (Covid19.Go.Id, 2021). Pertarungan dengan covid-19 bukan hanya dengan penyakitnya tetapi juga pesan yang menyesatkan pun ikut menyertai (infodemik). Seperti kabar terbaru, "Beredar sebuah pesan berantai melalui Whatsapp yang mengatakan bahwa Grab Indonesia memberikan bantuan kepada warga Surabaya. Narasi dalam pesan tersebut mengatakan bahwa bantuan diberikan dalam bentuk pemberian sembako senilai Rp80 ribu ", "Beredar sebuah pesan melalui WhatsApp yang menyarankan untuk tidak mengonsumsi makanan dan minuman yang mengandung alkohol seperti tape serta minuman bersoda seperti Fanta setidaknya hingga 6 bulan setelah menerima kedua dosis vaksin Covid-19". Bahkan yang lebih memberikan informasi yang menyesatkan adalah, "Beredar sebuah artikel online dari dailyexpose.co.uk yang mengklaim data Public Health England (PHE) menunjukkan bahwa orang yang sudah divaksinasi lengkap atau mendapatkan dua dosis lebih banyak terpapar Varian Delta dan lebih rentan untuk meninggal " (covid19.go.id, 2021).

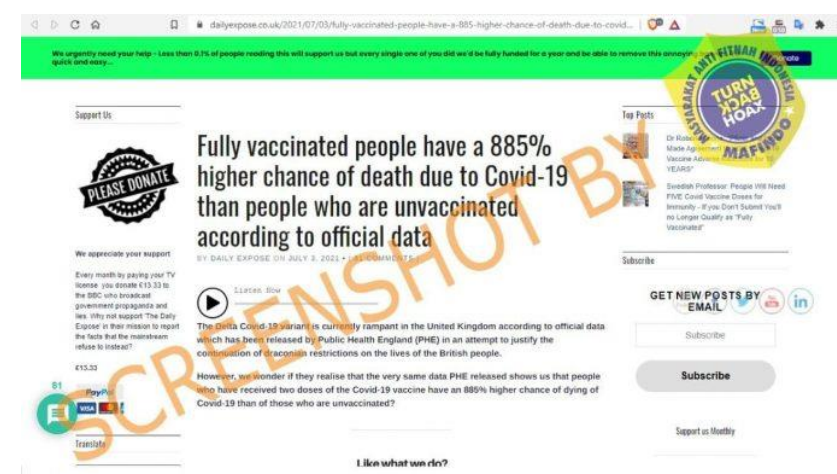

Gambar 1. Hoax varian Delta

Permasalahan yang timbul adalah bagaimana kondisi perkembangan teknologi informasi digital di masyarakat Indonesia agar dapat lebih memahami pandemi covid19 ini dan lebih ada kepastian bagi masyarakat. Karena, keterpaduan penelitian atau analisa mengenai kebutuhan masyarakat akan informasi dalam menghadapi pandemi covid-19 dengan teknologi informasi dapat mengembangkan aplikasi yang dibutuhkan masyarakat untuk menghadapi covid-19. Seperti yang diungkap Adiputra, ia menyatakan bahwa dalam informasi untuk kesehatan masyarakat dipastikan bahwa teknologi memberikan efektifitas dan efisiensi dalam mengerem laju penularan covid19 (Adiputra et al., 2020:1). Kejadian seperti kurangnya informasi yang akurat, membuat penderita covid-19 terlambat ditangani secara medis, berita tersebut dikabarkan suara.com pada edisi 12 Juli 2021 sehingga tidak akan terjadi kembali 
(Suara.com, 2021). Oleh karena itu, penelitian ini ingin mengambil data mengenai artikel penelitian yang ditulis pada masa pandemi, sehingga kita dapat melihat fenomena kebutuhan apa saja yang dibutuhkan oleh masyarakat untuk menghadapi pandemi covid-19 di Indonesia dan sisi mana yang kurang dan harus dipenuhi sehingga dapat dilakukan langkah strategis oleh pihak pemerintah. Data diambil dari penelitianpenelitian yang sebelumnya yang mengambil kasus mengenai pandemi covid-19 di Indonesia.

Didasari atas asumsi bahwa penelitian-penelitian yang ada tidaklah menjadi memadai apabila tidak dihubungkan satu sama lain. Penelitian yang tidak memperhatikan literature review sebelumnya tidak memberikan tingkat kebutuhan yang benar-benar sesuai yang dibutuhkan masyarakat. sehingga hasil-hasil penelitian mengenai pandemi covid-19 dapat memberikan manfaat untuk memasukkan langkahlangkah strategis bagi pemda ataupun pemerintah. Penelitian ini berupaya menghasilkan kesimpulan atas beberapa hasil penelitian dan pengemasan hasil penelitian sehingga bisa menghasilkan format actionable messages. Dengan melakukan sintesis hasil-hasil penelitian melalui pendekatan Systematic literaturee review dan menyajikannya dalam bentuk actionable.

\section{Metode}

Systematic literature review adalah suatu metode penelitian yang dapat digunakan untuk identifikasi, evaluasi, dan interpretasi pada hasil-hasil penelitian yang sudah dihasilkan dan sesuai mengenai pertanyaan penelitian, topik tertentu, atau fenomena yang untuk menjadi perhatian dalam penelitian ini adalah pandemi covid-19.

Word Health Organization (WHO, 2004:108), memberikan garis besar bila peneliti melakukan Systematic literaturee review dengan hirarki metode penyajian fakta kepada peneliti sebagai berikut:

(i) Inovasi dalam ranah teori, metodologi dan penelitian dasar,

(ii) Laporan penelitian tunggal dan artikel,

(iii) Sintesis hasil penelitian: meta-analisis, meta-sintesis),

(iv) Masukan untuk penentu kebijakan (actionable message: policy brief dan policy paper). Secara hirarkis, jenjang metodologi "research into action" agar mudah dipakai oleh penentu kebijakan.

Systematic literaturee review akan sangat bermanfaat dalam melakukan sintesis atau kumulatif dari berbagai hasil penelitian yang relevan, sehingga fakta yang disajikan kepada penentu kebijakan menjadi lebih komprehensif dan berimbang (WHO, 2004:329). Dengan menerapkan metodologi yang ketat dan transparan dalam sintesis penelitian Systematic literature review untuk mengurangi kesalahan sistematis (bias) yang mengganggu proses analisis data sekunder. Systematic literature review semakin sering digunakan untuk menginformasikan keputusan layanan kesehatan seperti apakah intervensi layanan kesehatan tertentu harus digunakan atau tidak dan dapat berkontribusi untuk menyelamatkan kehidupan, dan memacu penelitian (World Health Organization, 2004). 


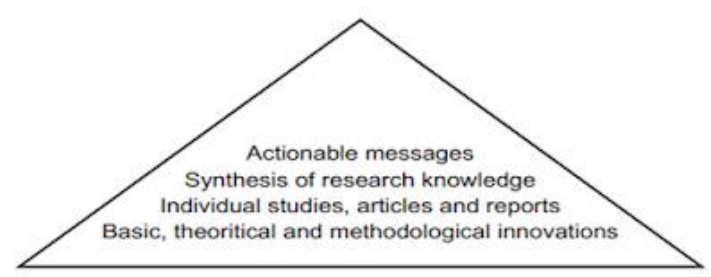

Gambar 2. Hirarki Metodologi Penelitian untuk Masukan Kebijakan (WHO, 2004)

Tampak dari gambar bahwa dari Systematic literaturee review ini, agar dapat dipakai oleh penentu kebijakan masih melalui dua tahap lagi, yakni sintesis (Systematic literaturee review) dan pengemasan hasil penelitian menjadi pesan yang mudah dipahami (actionable messages) berupa policy brief dan policy paper.

\section{Hasil dan Pembahasan}

Kebutuhan akan layanan informasi kesehatan dalam bentuk digital yang mudah diakses sangat diperljukan dengan keadaan pandemi covid-19 yang mengharuskan masyarakat Indonesia berhati-hati ke luar rumah. Aplikasi akan kesehatan atau pencegahan akan covid-19 sangatlah dibutuhkan sekali. Pemberlakuan Pembatasan Kegiatan Masyarakat (PPKM) di masyarakat sebagai kebijakan Pemerintah Indonesia sejak awal tahun 2021 untuk menangani pandemi Covid-19 di Indonesia membuat masyarakat semakin terbatasi aktivitasnya ke luar rumah. Penggunaan media internet di Indonesia pada masa pandemi covid-19 mengalami peningkatan medio 2020 mencapai 40\%, dalam laporannya APJII 2019-2020 memberikan angka total pengguna internet di Indonesia mencapai lebih dari 196 juta jiwa atau 72\% dari seluruh penduduk di Indonesia. Hanya di daerah Maluku dan Papua pengguna internetnya tidak sebanyak di pulau Jawa $(55,7 \%)$, di dua daerah tersebut pengguna internet hanya sekitar $3 \%$ dari total pengguna di Indonesia (Irawan et al., 2020). Bahkan di Google playstore sudah tersedia aplikasi yang memberikan informasi terkait pandemi covid-19, dengan kata kunci "Covid-19" ada 14 aplikasi tersedia, dan hanya 4 yang bisa diakses dengan mudah sisanya agak sulit untuk mengakses dan ini menjadi kendala bila dikatakan teknologi digital mempermudah akses tentang informasi pandemi covid-19.
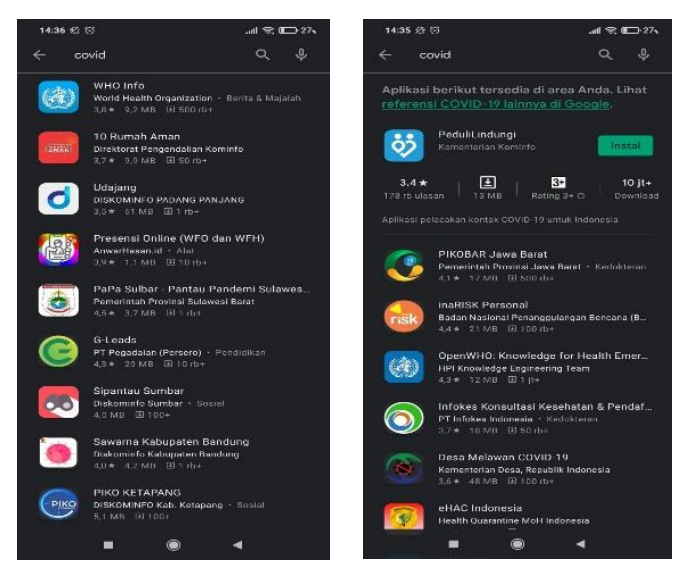

Gambar 3. Aplikasi covid-19 di Google Playstore 


\section{Aplikasi di Android mengenai covid-19}

Smartphone merupakan perangkat seluler yang dilengkapi dengan sistem operasi seperti halnya sebuah komputer. Smartphone dapat mengimplementasikan berbagai bentuk multimedia dengan kemampuan memiliki mobilitas yang tinggi dan dapat dioperasikan secara lebih efektif . aplikasi di android dapat dengan mudah diunduh oleh para pengguna smartphone di google playstore. Aplikasi yang dapat mudah diakses dari manapun yaitu:

\section{Peduli Lindungi}

Peduli Lindungi merupakan sebuah aplikasi yang dikembangan langsung oleh Kementerian Kominfo dan memiliki tujuan untuk membantu menghentikan penyebaran Virus Covid-19 di tengah masyarakat. Cara kerja aplikasi ini adalah dengan mengandalkan partisipasi masyarakat untuk saling membagikan data lokasinya saat berpergian pada aplikasi, agar pelacakan riwayat kontak dengan penderita Covid-19 mudah dilakukan.

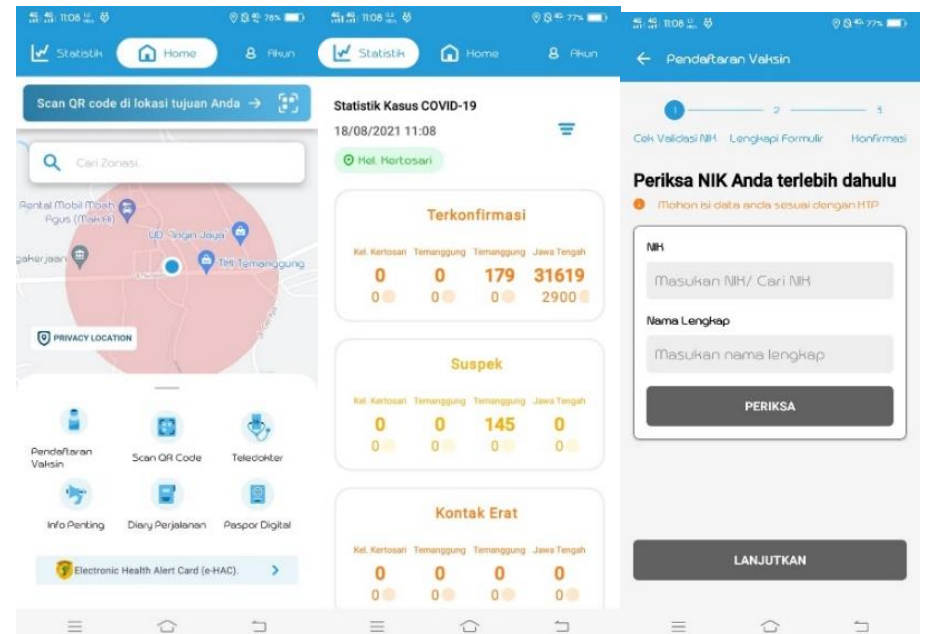

Gambar 4. Aplikasi Peduli Lindungi di Google Playstore

Aplikasi Peduli Lindungi turut menyediakan informasi mengenai lokasi di sekitar pengguna yang memiliki kasus aktif dan informasi rumah sakit serta apotek terdekat. Pengguna juga bisa mendapatkan notifikasi secara realtime apabila sedang berada di zona merah Covid-19. Fitur lainnya yang ada di dalam aplikasi ini bernama Teledokter, fitur ini dapat digunakan apabila pengguna ingin melakukan pemeriksaan mandiri dan berkonsultasi dengan tenaga kesehatan. Pengguna juga bisa mendapat vaksinasi beserta sertifikat vaksin dengan mendaftarkan diri ada aplikasi ini. Caranya dengan membuat akun pada aplikasi dan mengisikan data pada formulir pendaftaran, kemudian pengguna akan mendapatkan informasi mengenai jadwal pelaksanaan vaksinasi.

Aplikasi yang dirilis pada tanggal 28 Maret 2020 ini telah diunduh lebih dari 10 juta kali dan mendapat rating rata-rata sebanyak 3,4 dari 5. Beberapa pengguna memberikan ulasan positif mengenai sertifikat vaksin yang berbentuk digital sehingga mudah digunakan, serta kemudahan mendapat informasi mengenai penyebaran Covid19 di sekitar pengguna. Namun beberapa pengguna menuliskan ulasan negatif terkait 
bug pada aplikasi, serta proses untuk mendapatkan sertifikat vaksin yang memakan waktu hingga berminggu-minggu.

\section{Desa Melawan Covid-19}

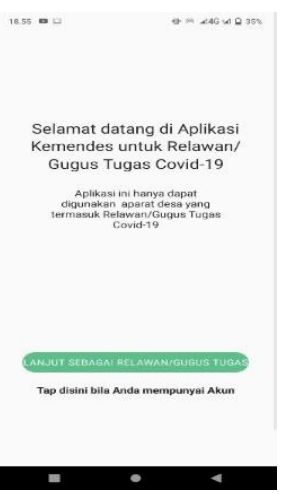

Gambar 5. Aplikasi Desa Melawan Covid-19 di Google Playstore

Aplikasi Desa Melawan Covid-19 adalah sebuah aplikasi yang dapat membatu para relawan untuk mendukung pencegahan penyebaran Covid-19 di desa, serta melakukan pendampingan desa dan pemantauan sosial dalam penyelenggaraan program penanganan dampak Covid-19. Aplikasi yang dikembangkan oleh Kementerian Desa, Pembangunan Daerah Tertinggal dan Transmigrasi (Kemendes PDTT) ini hanya bisa digunakan oleh relawan atau gugus tugas Covid-19. Aplikasi ini bertujuan untuk mengumpulkan data secara realtime terkait penyebaran Covid-19 di desa melalui relawan yang bertugas mengirimkan laporan mingguan dan bulanan melalui aplikasi ini. Relawan juga bisa mengedukasi masyarakat dengan materi mengenai pencegahan Covid-19 yang bisa diakses melalui aplikasi Desa Melawan Covid-19. Aplikasi ini turut membantu para relawan menjalankan kegiatan gugus tugas melalui fitur Kegiatan Gugus Tugas yang berisi panduan tentang kegiatan apa saja yang harus dikerjakan oleh gugus tugas.

Aplikasi ini pertama kali rilis pada tanggal 31 Julid 2020 dan telah diunduh lebih dari seratus ribu kali. Beberapa pengguna menuliskan ulasan positif mengenai kemudahan dalam memantau kondisi pandemi sampai ke tingkat dusun dan memudahkan pekerjaan pelaporan bagi relawan melalui aplikasi ini. Terdapat pula beberapa ulasan negatif terkait bug dalam aplikasi yang menyebabkan aplikasi gagal berfungsi, gagal login, serta proses loading memakan waktu yang cukup lama.

\section{Rumah Aman}

Aplikasi 10 Rumah Aman merupakan aplikasi yang dikembangkan oleh Direktorat Pengendalian Kominfo yang bekerjasama dengan Kantor Staf Presiden (KSP). Melalui aplikasi ini, Kementerian Kominfo dan KSP mengajak masyarakat Indonesia untuk saling bekerjasama dan berbagi informasi dalam menghadapi pandemi Covid-19. Aplikasi ini dilengkapi oleh teknologi kecerdasan buatan yang mampu untuk menghubungkan data berbasis peta melalui perangkat telepon seluler dan terhubung dengan berbagai platform sosial media. Banyak fitur yang ditawarkan oleh aplikasi ini, salah satunya 
adalah fitur pengukuran suhu tubuh yang dilakukan secara berkala dan peta untuk memantau suhu tubuh orang-orang di sekitar pengguna. Apabila suhu tubuh pengguna berada diatas 37,5 derajat Celcius, maka pengguna bisa melakukan pemeriksaan kesehatan mandiri berbasis kecerdasan buatan. Aplikasi ini juga memuat konten edukasional bagi masyarakat mengenai penjelasan bagaimana cara menghadapi virus serta upaya dalam pencegahan penyebaran virus Covid-19.

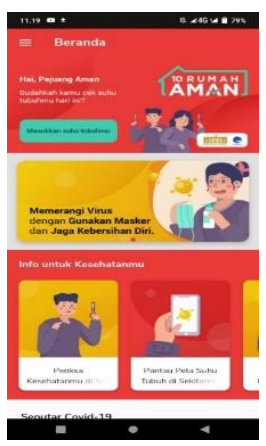

Gambar 6. Aplikasi Rumah Aman di Google Playstore

Terdapat pula fitur bernama Pejuang Aman dalam aplikasi ini. Melalui fitur Pejuang Aman, pengguna diminta melakukan misi 10 Rumah Aman dengan mengajak dan memastikan sekurang-kurangnya 10 keluarga yang berada di sekitar pengguna untuk ikut berpartisipasi dengan mengunduh dan menggunakan aplikasi ini. Aplikasi 10 Rumah Aman sudah terhubung dengan beberapa toko daring untuk memudahkan masyarakat dalam mendapatkan kebutuhan sehari-hari selama isolasi mandiri seperti SayurBox, Rego Pantes, dan TaniHub. Aplikasi ini juga terhubung dengan banyak apotek dan toko alat kesehatan seperti, Kimia Farma, Mediv-Kimia Farma serta Alfamind. Aplikasi ini pertama kali dirilis pada tanggal 27 Maret 2020 dan sudah diunduh lebih dari 50 ribu kali sampai saat ini. Aplikasi ini mendapat ulasan rata-rata sebesar 3,7 dari 5 di Google Play Store. Beberapa pengguna menulis ulasan positif terkait informasi wilayah rawan Covid-19, praktis dan efektif untuk memantau kondisi kesehatan keluarga dan warga sekitar, dan konten edukasi yang bermanfaat bagi masyarakat.

\section{inaRISK Personal}

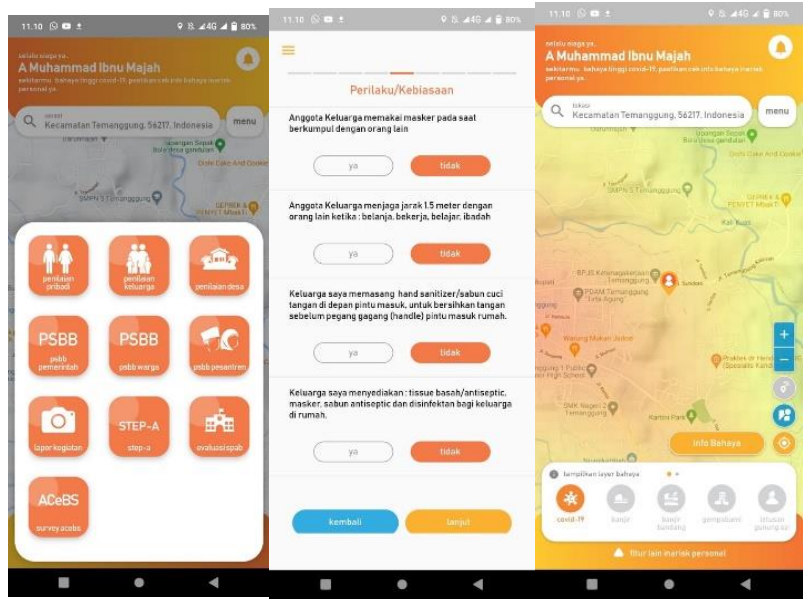

Gambar 7. Aplikasi InaRisk Personal di Google Playstore 
inaRISK Personal merupakan aplikasi yang dikembangkan oleh Badan Nasional Penanggulangan Bencana (BNPB) dan sudah dirilis sejak tanggal 28 Oktober 2017. Aplikasi ini awalnya bertujuan untuk memberikan informasi kepada pengguna mengenai bahaya kebencanaan disekitar seperti gempabumi, tanah longsor, letusan gung berapi, dan banjir bandang. Namun sejak virus Covid-19 meluas di Indonesia, BNPB menambahkan beberapa fitur baru pada aplikasi ini untuk turut membantu dalam pencegahan penyebaran virus. Pengguna dapat melihat peta persebaran Covid-19 di seluruh Indonesia melalui aplikasi ini. Pengguna juga bisa melakukan penilaian secara mandiri untuk mengetahui risiko pribadi, keluarga dan desa terkait Covid-19 dengan menjawab pertanyaan yang telah disediakan dalam aplikasi. Aplikasi ini juga memiliki fitur penilaian terhadap program pembatasan kegiatan dari pemerintah, warga, serta pesantren untuk membantu evaluasi pelasanaan pembatasan kegiatan di suatu tempat. Selain itu terdapat fitur Lapor Kegiatan yang dapat dimanfaatkan untuk melaporkan kegiatan atau kerumunan yang berpotensi meningkatkan penyebaran virus di tengah masyarakat.

Sejak pertama dirilis, aplikasi ini telah diunduh sebanyak 100 ribu kali hingga saat ini dan mendapat rating tinggi di Google Play Store yaitu sebanyak 4,4 dari 5. Beberapa pengguna menulis ulasan positif mengenai kemudahan informasi penyebaran virus Covid-19 sampai ke tingkat desa, serta informasi yang ditampilkan dalam aplikasi merupakan informasi yang terbaru. Namun terdapat beberapa pengguna yang menuliskan ulasan negatif terkait bug dalam aplikasi yang menyebabkan aplikasi gagal berfungsi, serta gagal menampilkan peta

Pembuatan aplikasi tersebut tidak didukung dalam penggunaannya di masyarakat dengan hanya diunduh di bawah 1 juta padahal penderita covid-19 di Indonesia hampir mencapai 4 juta di Indonesia dengan angka meninggal mencapai seratus ribu lebih jiwa. Ini menjadi pertanyaan besar apakah riset atau penelitian ilmiah di jurnal telah memberikan data keinginan dan kebutuhan masyarakat Indonesia sehingga dapat menjawab bahwa aplikasi-aplikasi yang dibutuhkan masyarakat Indonesia. Dengan menggunakan metode systematic review dengan dimulai dari pertanyaan penelitian, Permasalahan yang timbul adalah bagaimana kondisi perkembangan teknologi informasi digital di masyarakat Indonesia agar dapat lebih memahami pandemi covid-19 ini dengan lebih ada kepastian. Keterpaduan penelitian yang ada (diambil dari awal 2021 menggunakan Mendeley), analisa mengenai kebutuhan masyarakat dalam menghadapi pandemi covid-19 dengan teknologi informasi dalam informasi untuk kesehatan masyarakat dipastikan memberikan efektifitas dan efisiensi dalam mengerem laju penularan covid-19.

\section{Identifikasi Literatur yang sesuai}

Penggunaan metode systematic review dimulai dengan menggunakan aplikasi references manager manager dengan menggunakan kata kuncinya "Covid-19" dan mendapatkan hampir sebanyak 2.800 penelitian, dan kemudian diambil dari rentang 
Januari 2021 - Agustus 2021 (PPKM Mandiri). Data itu kemudian direduksi kembali yang membawa isu Teknologi informasi mengenai covid-19 dan penelitian ada di wilayah Indonesia. Data penelitian didapatkan sejumlah 80 Artikel penelitian dan dianalisa. Temuan tematik yang didapat adalah Pandemi Covid-19 memberikan pengaruh terhadap akses perkembangan teknologi di Indonesia. Pada bidang Pendidikan, aktivitas pembelajaran digital di era pandemi memberikan pengaruh terhadap efektivitas sistem pembelajaran secara online. Berbagai aktivitas pembelajaran secara online ini salah satunya dapat diketahui pada sistem fungsional literasi digital pada sebuah literasi digital perpustakaan (Husna et al., 2021)

Dalam kaitannya teknologi terhadap aktivitas pembelajaran ditemukan bahwa aktivitas pembelajaran online ditengah pandemi Covid-19 fokus membahas mengenai efektivitas teknologi digital bagi tenaga pendidik, bagaimana mutu pembelajaran online bagi para mahasiswa di perguruan tinggi, serta membahas mengenai efektifitas evaluasi pembelajaran terhadap motivasi siswa dalam pemanfaatan teknologi digital sebagai akses pembelajaran. Pada sebuah penelitian ditemukan bahwasanya kehadiran teknologi pada lingkup pendidikan berpengaruh terhadap pemanfaatan teknologi digital dalam hal penggunaan beberapa aplikasi diantaranya aplikasi padlet sebagai alternatif media pembelajaran daring, serta aplikasi fx-draw yang dimanfaatkan untuk meningkatkan kemampuan tenaga pendidik selama aktivitas pembelajaran daring.

Dari hasil coding mengenai perkembangan teknologi digital dan pandemi Covid19 ditemukan bahwa terdapat faktor lain yang mempengaruhi pembelajaran online dimasa pandemi diantaranya membahas mengenai kendala dan dampak yang ditimbulkan dari pembelajaran secara online oleh para peserta didik, serta adaptasi pembelajaran dengan memaksimalkan penggunaan E-Learning atau Learning Management System sebagai proses monitoring pelaksanaan pembelajaran oleh setiap peserta didik.

Pada bidang ekonomi, penggunaan teknologi digital di tengah pandemi Covid19 digunakan sebagai akses transaksi online yang meliputi e-commerce sebagai situs yang menyediakan berbagai produk kepada para calon pembeli. Dari beberapa jurnal memaparkan bahwa teknologi digital ditengah mewabahnya pandemi covid-19 ini telah mengangkat para pelaku usaha UMKM dalam memanfaatkan teknologi dengan menggunakan marketplace serta social media platform untuk meningkatkan daya beli masyarakat. Pelaku bisnis UMKM ini menggunakan teknologi digital sebagai strategi dalam melakukan digital marketing. Beberapa pelaku usaha juta melakukan pemanfaatan teknologi digital sebagai pelatihan untuk membuat Video Company Profile sebagai pendukung untuk menginformasikan promosi produk yang ditawarkan (Kussanti et al., 2021).

\section{Klaster Penelitian Teknologi Digital Pada Masa Pandemi Covid-19}


Adapun faktor lain yang menjelaskan penggunaan teknologi digital sebagai aktivitas kegiatan ekonomi diantaranya memanfaatkan digital marketing sebagai sasaran utama bagi para pelaku usaha dalam memperluas jangkauan pasar, pembuatan teknologi platform digital media sosial sebagai pemasaran yang tepat guna, serta pemanfaatan teknologi bagi para akuntan perbankan sebagai tata kelola literasi keuangan yang tepat ditengah pandemi.

Pada bidang teknologi informasi dan digital terdapat setidaknya 7 jurnal penelitian yang membahas perkembangan teknologi digital pada masa pandemic Civid19, diantaranya penggunaan teknologi dimanfaatkan sebagai akses untuk memaksimalkan fungsi dalam perkembangan techlash yang dilatarbelakangi oleh kemampuan untuk membuat kecerdasan buatan melalui cyber physical system, hingga internet of things (Tedjasuksmana, 2021), serta pemanfaatan media sosial sebagai media untuk memaksimalkan potensi penggunaan podcast audio(Marpaung et al., 2021).

Adapun faktor lain dalam pemanfaatan teknologi digital ini dalam beberapa jurnal menjelaskan untuk mengidentifikasikan framing dalam pemberitaan media terkait beberapa promosi di bidang pariwisata (Prayoga, 2021), mengidentifikasikan pengaruh digital payment terhadap penggunaan platform digital payment, serta mengidentifikasikan penggunaan monitoring pulsa berbasis Internet Of Things (Ardi Wibowo et al., 2021).

Pada bidang teologi dan agama terdapat 3 penelitian yang membahas mengenai teknologi digital pada masa pandemi Covid-19, diantaranta pemanfaatan teknologi disinyalir memanfaatkan teknologi sebagai media dalam menyediakan bacaan Alkitab secara online sebagai media yang memudahkan dalam menerapkan ibadah di masa pandemic (Sunarto, 2021). Faktor lain yang dipaparkan dalam beberapa jurnal menjelaskan mengenai implementasi pemerintah dalam penanganan pandemic Covid19 melalui pendekatan agama islam dalam kanal media offline dan online (Sugara \& Ulfa, 2021), serta penggunaan konsep Religious-Social Shaping of Technology sebagai media dalam melakukan ibadah dan mediasi bagi para umat Katolik (Tonggo \& Irwansyah, 2021).

Dalam bidang hukum penelitian mengenai teknologi dan Covid-19 terdapat 2 jurnal penelitian yang menjelaskan penggunaan teknologi dimanfaatkan sebagai pendataan untuk memproteksi kekayaan intelektual secara yuridis (Ramli et al., 2021), serta pemanfaatan teknologi sebagai media untuk pembuatan kebijakan mengenai upaya mengatasi Covid-19 (Danurahman \& Kusdarini, 2021).

Dalam kajian bidang kesehatan, pemanfaatan teknologi digunakan sebagai untuk membuat aplikasi e-health dengan proses melalui observasi kebutuhan informasi menggunakan platform android (Abdikarya et al., 2021), serta pemanfaatan teknologi 
sebagai pemberian informasi mengenai pengetahuan pola hidup sehat dan bersih (PHBS) atau penerapan protokol kesehatan untuk mengantisipasi pencegahan Covid19 bagi para kuliah kerja nyata mahasiswa (KKNM) (Raharjo, 2021).

Selanjutnya dalam kajian perkembangan teknologi berbasis internet dibahas dialam 1 jurnal penilitian diantaranya, teknologi memberikan pengaruh terhadap cyber digital yang dapat menyebabkan kurangnya pengawasan oleh orang tua terhadap ancaman komunikasi perundungan yang berbentuk cyber bullying (Ruliyatin \& Ridhowati, 2021).

Pengumpulan data dari hasil coding juga memperoleh kajian mengenai teknologi dan penggunaan media sosial dalam 1 jurnal penelitian yang membahas mengenai pemanfaatan media sosial sebagai media dalam mengakses layanan perpustakaan untuk mengetahui grafik jumlah pengunjung dan koleksi buku di tengah pandemi (KIANTINI, 2021).

Selanjutnya penggunaan digital juga mempengaruhi kajian bidang sosial dan budaya dalam 1 jurnal penelitian diantaranya membahas peningkatan pengembangan pariwisata masyarakat dalam proses pembangunan berkelanjutan, serta pemanfaatan media sosial sebagai revitalisasi permainan tradisional anak (Sonjaya et al., 2021).

Dari pengumpulan data hasil coding melalui beberapa jurnal penelitian mengenai kaitannya digital teknologi dan Covid-19 memaparkan bahwa dalam kurun tujuh bulan terakhir, hasil penelitian digital teknologi dan Covid-19 banyak membahas mengenai pemanfaatan teknologi pada kajian bidang pembelajaran pendidikan serta pemanfaatan teknologi digital dalam kajian bidang pemasaran ekonomi.

Trend teknologi digital dan pandemic Covid-19 yang membahas mengenai ruang lingkup pendidikan dan ekonomi menjadi topik yang sering dibahas dalam kajian penelitian. Terdapat setidaknya 28 jurnal penelitian yang membahas mengenai kajian penelitian teknologi digital pada bidang pendidikan di tengah pandemic Covid-19. Sedangkan sebanyak 22 jurnal penelitian membahas mengenai kaitannya teknologi digital pada kajian bidang ekonomi pemasaran di tengah pandemi Covid-19.

Adapun jurnal penelitian yang membahas mengenai kajian penelitian teknologi digital pada bidang pendidikan diantaranya, Membahas efektivitas teknologi digital dalam pembelajaran Secara daring selama pandemi Covid-19 serta dampak terhadap otak para peserta didik (Rahma \& Arista, 2021), membahas mengenai pembangunan literasi fungsional di masa pandemic (Husna et al., 2021), pengaruh pemanfaatan teknologi digital terhadap peran orang tua pada anak usia dini (Asmawati, 2021), Penggunaaan aplikasi padlet sebagai alternatif media pembelajaran daring selama pandemic covid 19 (Ambarita, 2021), Pemanfaatan modul elektronik dalam proses pembelajaran selama daring (Ernawati \& Susanti, 2021), Penggunaan media digital pembelajaran daring seperti internet dan e-learning (Astriani \& Marzuki, 2021), 
Pemanfaatan dalam pendampingan penguasaan aplikasi fx-draw untuk meningkatkan kemampuan guru dalam mengembangkan bahan ajar matematika selama pembelajaran daring (Jamil et al., 2021), Membahas mengenai kendala yang terjadi saat kegiatan pembelajaran jarak jauh selama pandemi Covid-19 (Fikri, 2021), Serta membahas mengenai learning management System yang terpadu dalam mengintegrasi proses pembelajaran melalui monitoring dan evaluasi demi terjaminnya mutu dan kualitas pembelajaran di masa pandemi dengan memanfaatkan Pingdom tools, GTMetrix, webpage test dan Load storm (Tandirerung, 2021).

Sedangkan hasil penelitian yang membahas mengenai teknologi digital pada kajian bidang ekonomi pemasaran di tengah pandemi Covid-19 diantaranya yaitu, membahas mengenai transaksi keuangan digital dengan memanfaatkan marketplace seperti web, instagram, shopee, dan lazada maupun bukalapak (Tresna Ningsih, 2021), pendampingan pemanfaatan teknologi informasi untuk pencatatan transaksi keuangan (Fachrunnisa et al., 2021), pemanfaatan digital marketing dengan memanfaatkan media sosial bagi para pelaku UMKM (Taufiqurrahman et al., 2021), Implementasi Ekonomi Digital pada penelitian ini berupa pemanfaatan TIK dalam bentuk Digital Capital yang merupakan akumulasi pemanfaatan kompetensi digital dengan teknologi digital (Rahmadan et al., 2021), Pelatihan Video Company Profile Sebagai Penunjang Informasi dan Promosi pada AMI di Masa Pandemi Covid-19 (Kussanti et al., 2021), Analisis Strategi Bertahan Bisnis Di Tengah Pendemi Covid-19 Dengan Memanfaatkan Bisnis Digital pada usaha kecil dan menengah (UKM) (Avriyanti, 2021), Optimalisasi Strategi Pemasaran Digital UMKM selama Pandemi Covid-19 (Mavilinda et al., 2021), Literasi akuntansi dan tatakelola keuangan berbasis teknologi untuk pelaku UMKM di masa Pandemi Covid-19 (Sailendra et al., 2021), serta membahas mengenai dampak perkembangan dan prospek Perbankan Syariah selama Pandemi Covid-19 (Safitri et al., 2021).

Berbagai penelitian mengenai teknologi digital dan Covid-19 lebih banyak membahas mengenai kajian penelitian Perkembangan teknologi digital di bidang pendidikan pembelajaran dan ekonomi pemasaran. Perlu diketahui bahwasanya masyarakat di tengah pandemi covid-19 saat ini justru membutuhkan akses ketersediaan layanan teknologi digital pada bidang kesehatan. Namun pada nyatanya dari hasil penelitian terdapat setidaknya 2 penelitian yang membahas mengenai kesehatan yaitu, membahas mengenai pembuatan aplikasi e-health melalui observasi kebutuhan informasi dan menu melalui platform android (Abdikarya et al., 2021), serta membahas penelitian mengenai pemberian informasi dan pengetahuan mengenai pola hidup sehat dan bersih (PHBS) atau penerapan protokol kesehatan (prokes) untuk mencegah penyebaran Covid-19 (Raharjo, 2021).

Setelah ditelusuri melalui pendekatan holistik, kurangnya penelitian mengenai perkembangan teknologi digital dan covit-19 pada bidang kesehatan ini dilatarbelakangi oleh lambatnya akses ketersediaan layanan kesehatan pada beberapa aplikasi. Hal ini 
menunjukkan bahwasanya perkembangan ilmu pengetahuan dan teknologi Indonesia masih kurang efektif untuk memberikan layanan secara optimal kepada masyarakat.

\section{Ekstraksi Data Penelitian}

Fokus pemerintah yang mengedepankan konsep penanganan wabah virus corona masih dalam taraf mekanisme testing, tracing, fencing atau isolating, dan treatment ini hanya berfokus dalam upaya untuk memperbaiki pengelolaan potensi riset dan inovasi teknologi sehingga masih minim dalam pengorientasian untuk mengentaskan wabah covid-19. (Sudrajat et al., 2020). Masyarakat yang sangat membutuhkan akses layanan kesehatan mengenai Covid-19 saat ini seharusnya didukung dengam ketersediaan teknologi digital yang efisien dalam menangani infodemiologi dan infoveillance. Informasi mengenai teknologi digital yang menyertai untuk mencegah dan membantu penanggulangan pandemi covid-19 masih sedikit. Perhatian pemerintah hanya pada himbauan untuk melakukan 3M, yaitu Perilaku disiplin 3M termasuk dalam kampanye untuk menekan penyebaran virus Covid-19. Penerapan 3M untuk pencegahan Covid-19 dapat dilakukan dengan: Memakai masker, Mencuci tangan, Menjaga jarak dan menghindari kerumunan. Kekuatan untuk teknologi digital tidak menjadi perhatian banyak masyarakat dilihat dari penelitian yang banyak mengarah pada bidang pendidikan pembelajaran dan ekonomi pemasaran.

\section{Simpulan}

Kecenderungan penelitian terkait teknologi digital selama pandemi covid-19 (dari Januari 2021 - Agustus) pada masa PPKM mandiri memperlihatkan ketertarikan masyarakat dalam menanggulangi masalah-masalah dan bangkit dari pandemi covid19. Dalam cluster dan coding permasalahan terfilter dari data artikel-artikel penelitian yang ada, terbanyak adalah meneliti permasalahan di bidang pendidikan dan ekonomi. Pendidian daring juga banyak sekali ditulis dalam artikel di masa PPKM karena dibatasinya pembelajaran tatap muka dan mengharuskan pembelajaran dengan sifat online yang mengharuskan menggunakan teknologi pembelajaran yang bersifat digital. Ekonomi juga menjadi bidang yang sangat diperhatikan dalam masa pandemi, bagaimana peningkatan ekonomi harus selalu diperjuangkan karena begitu turunnya daya beli masyarakat dan rendahnya transaksi perdagangan di masyarakat. Tetapi program PPKM yang dilaksanakan penerintah Indonesia itu adalah untuk menurunkan angka pasien dan kematian karena pandemi covid-19 tidak terlalu diperhatikan dalam penelitian-penelitian dalam medio Januari-Agustus. Sehingga sangat perlu kiranya penelitian mengenai bagaimana penelitian tentang teknologi digital untuk menekan laju kematian dan pasien covid-19. Penelitian ini juga akan menjadi program yang perlu diperhatikan pemerintah untuk menekan laju penderita covid-19. Setidaknya ada penelitian mengenai strategi komunikasi digital yang memberikan pengetahuan atau literasi mengenai penggunaan teknologi digital ke masyarakat agar masyarakat memiliki pengetahuan cukup mengenai pandemi covid-19. 


\section{Daftar Pustaka}

Adiputra, mahayasa, Mulana, A., \& Farmani, I. (2020). Platform Informatika Kesehatan Masyarakat Dalam Kasus COVID-19 di Bali. Jurnal Manajemen Informasi Kesehatan Indonesia (JMIKI), 8(2), 163. https://doi.org/10.33560/JMIKI.V8I2.284

Arifin, R. (2016). Pemanfaatan Teknologi Informasi dalam Penanggulangan Bencana Alam di Indonesia Berbasiskan Web. Bina Insani ICT Journal, 3(1), 234348.

covid19.go.id. (2021). [SALAH] Hasil Perhitungan Data Orang yang Sudah Divaksinasi Lebih Banyak Terpapar Varian Delta dan Peluang Kematian Lebih Tinggi - Hoax Buster / Covid19.go.id. https://covid19.go.id/p/hoax-buster/salah-hasil-perhitungan-data-orang-yang-sudahdivaksinasi-lebih-banyak-terpapar-varian-delta-dan-peluang-kematian-lebih-tinggi

Irawan, aditya wicaksono, Yusufianto, A., Agustina, D., \& Dean, R. (2020). Laporan Survei Internet APJII 2019 - 2020. Asosiasi Penyelenggara Jasa Internet Indonesia, 2020, 1-146. https://apjii.or.id/survei

Kedatangan Vaksin COVID-19 Tahap Ke-36: 5 Juta Dosis Vaksin Jadi Sinovac (16 Agustus 2021) Masyarakat Umum I Covid19.go.id. (2021). Covid19.Go.Id. https://covid19.go.id/edukasi/masyarakat-umum/kedatangan-vaksin-covid-19-tahap-ke-36-5juta-dosis-vaksin-jadi-sinovac-16-agustus-2021

Liu, E., \& Sukmariningsih, R. M. (2021). Membangun model basis penggunaan teknologi digital bagi UMKM dalam masa pandemi Covid-19. Jurnal lus Constituendum, 6(April), 213-234. https://journals2.usm.ac.id/index.php/jic/article/view/3191

Nunes, M. (2006). Cyberspaces of Everyday Life. In Cyberspaces of Everyday Life. https://doi.org/loc?

Suara.com. (2021). Kurangnya Informasi yang Akurat, Bikin Pasien Covid-19 Terlambat Ditangani. https://www.suara.com/health/2021/07/12/085000/kurangnya-informasi-yang-akurat-bikinpasien-covid-19-terlambat-ditangani?page=all

WHO. (2004). World Report on Knowledge for Better Health: Strengthening Health Systems. In Bulletin of the World Health Organization. WHO Library Cataloguing-in-Publication Data World. https://doi.org/10.1590/S0042-96862005000100019

Yusuf. (2021). Kementerian Komunikasi dan Informatika. https://www.kominfo.go.id/content/detail/32602/pandemi-covid-19-pacu-adaptasi-gunakanteknologi-digital/0/berita_satker

Abdikarya, J., Karya, J., Dosen, P., Mahasiswa, D., Rohmah, M. K., Wahyuni, K. I., \& Ambari, Y. (2021). Edukasi dan Pendampingan Dalam Pencegahan COVID-19 Memulai Aplikasi E-Health Pada Mahasiswa Stikes Rumah Sakit Anwar Medika dan Keluarga. Januari, 04(1).

Ambarita, E. (2021). Belajar Dari Rumah (Bdr) Menggunakan Padlet Alternatif E-Learning Pada Masa Pandemi Covid-19 (Studi Kasus Di Sman 56 Jakarta). JIRA: Jurnal Inovasi Dan Riset Akademik, 2(1). https://doi.org/10.47387/jira.v2i1.70

Asmawati, L. (2021). Peran Orang Tua dalam Pemanfaatan Teknologi Digital pada Anak Usia Dini. Jurnal Obsesi : Jurnal Pendidikan Anak Usia Dini, 6(1). https://doi.org/10.31004/obsesi.v6i1.1170

Astriani, Y., \& Marzuki, I. (2021). PJJ: Digital Transformasi Daring Pada Evaluasi Pendidikan Di Era Pandemi Covid -19. Rausyan Fikr: Jurnal Pemikiran Dan Pencerahan, 17(1). https://doi.org/10.31000/rf.v17i1.4205

Avriyanti, S. (2021). Strategi bertahan bisnis di tengah pandemi covid-19 dengan memanfaatkan bisnis digital (studi pada ukm yang terdaftar pada dinas koperasi, usaha kecil dan menengah kabupaten Tabalong). Jurnal Stiatabalong, 5(1).

Ernawati, T., \& Susanti, S. (2021). E-Modul IPA 2 Untuk Pembelajaran Mandiri Di Masa Pandemi Covid19. KoPeN: Konferensi Pendidikan Nasional, 3(1).

Fachrunnisa, Z. H., Nazarilah, E. A., Nasianti, W., \& Ovita, A. (2021). Revitalisasi Kegiatan Usaha Getuk Goreng Hj. Tohirin di Masa Pandemi Covid-19. Al-Khidmat, 4(1). https://doi.org/10.15575/jak.v4i1.11757

Fikri, M. (2021). Kendala Dalam Pembelajaran Jarak Jauh di Masa Pandemi Covid-19 : Sebuah Kajian Kritis. Jurnal Education and Development Institut Pendidikan Tapanuli Selatan, 9(1). 
Husna, A. N., Yuliani, D., Rachmawati, T., Anggraini, D. E., Anwar, R., \& Utomo, R. (2021). Program Literasi Digital untuk Pengembangan Perpustakaan Berbasis Inklusi Sosial di Desa Sedayu, Muntilan, Magelang. Community Empowerment, 6(2). https://doi.org/10.31603/ce.4259

Jamil, A. F., Kusumawardana, A. S., \& Kholimi, A. S. (2021). Pendampingan Penguasaan Aplikasi Fx Draw Untuk Meningkatkan Kemampuan Guru Dalam Mengembangkan Bahan Ajar Matematika. Jurnal Buletin Al-Ribaath, 18(1). https://doi.org/10.29406/br.v18i1.2543

Kussanti, D. P., Fitriansyah, F., Erlangga, C. Y., \& Amalliah, A. (2021). Pelatihan Video Company Profile Sebagai Penunjang Informasi dan Promosi pada AMI di Masa Pandemi Covid-19. ABDIMASKU: JURNAL PENGABDIAN MASYARAKAT, 4(2). https://doi.org/10.33633/ja.v4i2.222

Mavilinda, H. F., Nazaruddin, A., Nofiawaty, N., \& Siregar, L. D. (2021). Menjadi “UMKM Unggul” Melalui Optimalisasi Strategi Pemasaran Digital dalam Menghadapi Tantangan Bisnis di Era New Normal. Sricommerce: Journal of Sriwijaya Community Services, 2(1). https://doi.org/10.29259/jscs.v2i1.29

Raharjo, S. T. (2021). PENGUATAN MASYARAKAT DI MASA PANDEMI COVID 19: KESEHATAN MENTAL PELAJAR. Jurnal Penelitian Dan Pengabdian Kepada Masyarakat (JPPM), 2(1). https://doi.org/10.24198/jppm.v2i1.33438

Rahma, A. A., \& Arista, H. (2021). ANALISIS PENERAPAN GOOGLE CLASSROOM UNTUK MENINGKATKAN MUTU PEMBELAJARAN ONLINE DI MASA PANDEMI COVID-19. Pedagogy : Jurnal IImiah Ilmu Pendidikan, 8(1). https://doi.org/10.51747/jp.v8i1.730

Rahmadan, R., Indrawari, I., \& Ridwan, E. (2021). Pengaruh Pandemi Covid-19 Terhadap Dampak Implementasi Ekonomi Digital Pada Umkm. Menara IImu, 15(1). https://doi.org/10.31869/mi.v15i1.2384

Safitri, A. N., Fasa, M. I., \& Suharto, S. (2021). Dampak Pandemi Covid-19 terhadap Perkembangan dan Prospek Perbankan Syariah. Economics and Digital Business Review, 2(2). https://doi.org/10.37531/ecotal.v2i2.66

Sailendra, S., Djaddang, S., Syam, M. A., Susilawati, S., \& P, N. (2021). Tatakelola Keuangan UMKM Berbasis ETAP dan Android Untuk Meningkatkan Efisiensi Kinerja Usaha pada Era Covid-19 Normal Baru. CAPACITAREA: Jurnal Pengabdian Kepada Masyarakat, 1(02). https://doi.org/10.35814/capacitarea.v1i02.2058

Sudrajat, I., Riza, H., Moehtadi, F., \& Panggabean, L. (2020). Peran Iptekin dalam mengatasi COVID-19: pembelajaran dari beberapa negara. Jurnal Sistem Cerdas, 3(2). https://doi.org/10.37396/jsc.v3i2.73

Tandirerung, V. A. (2021). Analisis Performansi LMS SYAM OK dalam Pembelajaran di UNM. Jurnal MediaTIK, 4(1). https://doi.org/10.26858/jmtik.v4i1.19967

Taufiqurrahman, T., Azis, A., \& Sugita, A. (2021). Pemberdayaan Ekonomi Masyarakat Melalui Dunia Digital di Era Covid-19. Etos: Jurnal Pengabdian Masyarakat, 3(1). https://doi.org/10.47453/etos.v3i1.351

Tresna Ningsih, I. K. W. (2021). kemajuan-ekonomi-digital-dari-sisi-e-commerce-di-era-pandemi-covid19-1102201. SOLOPOS.Com. 